\title{
Impacts of increasing maximum truck weight - case Finland
}

\author{
Heikki Liimatainen ${ }^{1 *} \mathbb{D}$, Markus Pölänen ${ }^{1}$ and Lasse Nykänen ${ }^{2}$
}

\begin{abstract}
Finnish government allowed in October 2013 operating high capacity vehicles (HCV) with a maximum weight limit of $76 \mathrm{t}$ on Finnish roads. An analysis on how HCVs have affected the Finnish road freight transport sector is presented here based on a continuous time series data from 2013 to 2017. The analysis shows a significant increase in the average payload weight and a transition from 7-axle to 8- and 9-axle articulated vehicle combinations, which allow the higher weights. Truck mileage of 225 million km has been avoided from October 2013 until the end of 2017 and avoided mileage corresponded in 2017 to approximately 4\% of total truck mileage in Finland. This equals around 126 million $€$ cost savings in 2017 and $0.1 \mathrm{Mt}$ of $\mathrm{CO}_{2}$ emissions reduction in road freight, even after taking into account that there has been some modal shift from rail to road.
\end{abstract}

Keywords: High capacity vehicles, Road freight transport, $\mathrm{CO}_{2}$ emissions, Transport costs

\section{Introduction}

Road freight transport is a significant contributor to global greenhouse gas (GHG) emissions and its importance in transport emissions is likely to increase as passenger vehicles are increasingly electrified. In addition to propulsion issues, also changes in consuming habits offer significant challenges, because more and more deliveries are made to customers' homes instead of local markets and shopping centres. Hence, each action, which could provide efficient improvements and emission reductions for transport sector must be considered. Without actual data and information it is impossible to determine which actions are good and influential and which are not. Hence studies as described in this paper are important for global battle against climate change.

Measures to decarbonise road freight transport are required in order to prioritize actions to mitigate climate change. One possible measure for reducing the GHG emissions and simultaneously deceasing the transport costs is using longer and heavier vehicles. This follows the basic principle that it is more efficient to transport large volumes consolidated into full truckloads, than to transport low volumes and part loads. Finland and Sweden have a long

\footnotetext{
* Correspondence: heikki.liimatainen@tuni.fi

${ }^{1}$ Transport Research Centre Verne, Tampere University, P.O. Box 600, FI-33014 Tampere, Finland

Full list of author information is available at the end of the article
}

tradition in using $25.25 \mathrm{~m}$ and $60 \mathrm{t}$ articulated vehicles, commonly referred to as long and heavy vehicles (LHVs), while other countries in Europe and North America mostly use $18.75 \mathrm{~m}$ and $44 \mathrm{t}$ vehicles, commonly referred to as heavy goods vehicles (HGVs). Finland and Sweden are also allowing and piloting even longer and heavier vehicles, referred to as high capacity vehicles (HCVs) or high capacity transport (HCT), with maximum weight of up to $104 \mathrm{t}$ and maximum length of up to $34.5 \mathrm{~m} \mathrm{[1]}$.

Finnish government allowed in October 2013 by amendment to Finnish legislation [2] the operation of high capacity vehicles $(\mathrm{HCV})$ with gross vehicle weight (GVW) of $76 \mathrm{t}$ on Finnish roads. On bridges and smaller roads, usage of $\mathrm{HCV}$ can be restricted with traffic signs, but otherwise $\mathrm{HCVs}$ can operate freely. This decision differs from general European legislation. By the new regulation the maximum weight limit of trucks increased to $76 \mathrm{t}$ and the maximum height limit to $4.4 \mathrm{~m}$ from the previous limits of $60 \mathrm{t}$ and $4.2 \mathrm{~m}$, while maintaining the length limit at $25.25 \mathrm{~m}$ in accordance with the European modular system. New regulation affected both new vehicles and vehicles that were already in operation. Hence, there was no need for hauliers to invest in new vehicles in order to benefit from the larger payload. Only an alteration inspection for the old vehicles were needed to allow the operations with increased payload. The changes in the truck weight limits are presented in Table 1. 
Table 1 Changes in the truck weight limits and payloads

\begin{tabular}{|c|c|c|c|c|c|}
\hline \multirow[b]{2}{*}{ Truck type } & \multicolumn{2}{|c|}{$\begin{array}{l}\text { Maximum gross vehicle } \\
\text { weight limit }\end{array}$} & \multicolumn{2}{|c|}{ Maximum payload weight } & \multirow[b]{2}{*}{ Increase in payload } \\
\hline & Old & New & Old & New & \\
\hline 4-axle truck without trailer & $32 \mathrm{t}$ & $35 t$ & $18 t$ & $21 \mathrm{t}$ & $17 \%$ \\
\hline 5-axle truck without trailer & $38 \mathrm{t}$ & $42 t$ & $21 \mathrm{t}$ & $25 \mathrm{t}$ & $19 \%$ \\
\hline 8-axle articulated truck & $60 t$ & $68 t$ & $37 t$ & $45 t$ & $22 \%$ \\
\hline 9-axle articulated truck & $60 t$ & $76 t$ & $35 t$ & $51 \mathrm{t}$ & $46 \%$ \\
\hline \multicolumn{6}{|c|}{$\begin{array}{l}\text { In addition, the amendment in regulation included temporary weight increases, which were in force until the end of April 2018. The } \\
\text { temporary increases were: }\end{array}$} \\
\hline 2-axle truck without trailer & $18 t$ & $20 t$ & $26 t$ & $28 \mathrm{t}$ & $18 \%$ \\
\hline 3-axle truck without trailer & $26 t$ & $28 t$ & $16 t$ & $18 \mathrm{t}$ & $13 \%$ \\
\hline 7-axle articulated truck & $60 t$ & $64 t$ & $40 t$ & $44 t$ & $10 \%$ \\
\hline
\end{tabular}

In addition to these changes, hauliers in Finland have been allowed, with exemption permissions on certain roads, to test even larger) articulated trucks of up to 104 $\mathrm{t}$ and $34.5 \mathrm{~m}$ long [1]. In spring 2018, there were altogether 50 pilot HCV combinations on Finnish roads, of which 32 were longer than $27 \mathrm{~m}$ and 18 were heavier than $76 \mathrm{t}$ [3]. After successful trials, in January 2019 the longest permitted length was extended to $34.50 \mathrm{~m}$ from the previous $25.25 \mathrm{~m}$ on all roads in Finland [4].

The purpose of this paper is to analyse how allowing the $76 t \mathrm{HCVs}$ have affected the transport volumes, costs and $\mathrm{CO}_{2}$ emissions of Finnish road freight transport sector. The paper also includes a comparison, where predicted impacts (see [5]) are compared with the actual impacts. The focus is on the articulated vehicles in the 60 to $76 \mathrm{t}$ range, i.e. the 7-, 8- and 9-axle vehicles. The maximum weight limits of trucks with $2-5$ axles were also changed, but higher weight limits have not been utilised with these smaller rigid trucks. As for the over $76 \mathrm{t}$ or over $25.25 \mathrm{~m}$ vehicles that have been operating in Finland, there is very limited amount of data available in general statistics so these vehicles are not considered in this study.

\section{Literature review}

Allowing the use of longer and heavier vehicles (LHVs) in Europe has been subject of active research during recent years and there has been some debate about the potential benefits and negative impacts. Most studies in Europe have focused on the transition from conventional heavy goods vehicles (HGV) with $18.75 \mathrm{~m}$ length and $40 \mathrm{t}$ gross vehicle weight (GVW) to the European modular system (EMS) with $25.25 \mathrm{~m}$ length and $60 \mathrm{t}$ GVW. Most studies agree that the larger the truck, the more efficient use of resources, meaning that using larger vehicles would increase transport efficiency (see [6-12];).

Sanchez Rodrigues et al. [12] note that the impacts of LHVs are usually estimated using road freight statistics, because of the lack of empirical data, but in their case study six German companies tested EMS vehicle combinations and all six companies reported cost reductions. The companies were able to reduce fuel consumption per tkm by about $30 \%$, but also negative outcomes were anticipated by some respondents, such as an increase in tyre costs and in vehicle maintenance costs. LHV trials in the Netherlands have resulted in reduced number of journeys and driven mileage, which are estimated to reduce 20 million kilometres annually and thus $0.016 \mathrm{Mt}$ reduction in $\mathrm{CO}_{2}$ emissions per year, according to Rijkswaterstaat [11]. Breemersch and Akkermans [7] estimated that allowing EMS operations in the EU could result in $2 \%$ reduction in $\mathrm{CO}_{2}$ emissions from long haul transport by 2020 .

The optimum size of vehicles has also received much attention in the LHV debate. Some studies claim that the largest vehicle combinations are risky and may cause more negative than positive impacts, although they agree that LHVs offer benefits $[8,13]$. Lumsden [14] notes that for majority of long haul transport the dimensions of the vehicle are more important than the maximum weight. Galos et al. [15] highlight that it is also possible to increase the payload by reducing the own weight of the truck by using lightweight materials, hence giving the opportunity increase the efficiency of hauling weight restricted commodities.

Sweden has a long tradition of using EMS. KysterHansen \& Sjögren [16] outline a roadmap on permitting high capacity vehicle combinations on Swedish roads and give recommendations on stakeholder activities to support the implementation. Vierth \& Haraldsson [17] and Örebro Regional Development Council [18] studied the shift from $60 \mathrm{t}$ to $90 \mathrm{t}$ trucks and report positive results with some notices. A shift from $60 \mathrm{t}$ to $90 \mathrm{t}$ could reduce the vehicle kilometres by about on third, according to Örebro Regional Development Council [18]. Pålsson et al. [19] estimated the effects of HCVs in Sweden and concluded that the net economic benefits of 
implementing $25.25 \mathrm{~m} / 74 \mathrm{t}$ vehicles would total 2.9 to 7.4 billion $€$ during 2018-2058, depending on the implementation scenario, but also require 1.1 to 1.3 billion $€$ additional investments in road infrastructure. Freight transport in the forestry sector have been seen as a particularly suitable area of implementing HCVs. Haraldsson et al. [20] have estimated that replacing $60 \mathrm{t}$ articulated trucks with $90 \mathrm{t}$ combinations in Swedish round wood transport would reduce vehicle kilometres by $21 \%$.

In Finland, Palander [21] analysed the actual effects of allowing HCVs in Finland using ERP data from a major Finnish pulp and paper company and concluded that operational reduction in fuel consumption was $6.2 \% 1$ year after the mass limits were raised from $60 \mathrm{t}$ to $76 \mathrm{t}$ in 2013 and long-term reduction could be $15.5 \%$, when hauliers are fully adjusted and implemented HCVs.

Most of the negative impacts of LHVs relate to concern a potential modal shift from rail to road, safety issues and the impacts on road infrastructure [10, 22]. TRL [23] estimates that LHVs would result in a significant modal shift and lead to an increase in $\mathrm{CO}_{2}$ emissions. However, Steer et al. [24] conclude that empirical evidence shows lower actual modal shift than desk studies have estimated. Several studies conclude that there is no clear evidence that LHVs would decrease road safety, and LHVs might even improve safety due to reduced truck mileage $[9,25,26]$. The impact of LHVs on the road infrastructure depends on the axle weights, number of axles and tyres. Kalliainen et al. [27] and Kolisoja et al. [28] argue that road wear may increase. Furthermore, investments in bridges may be required to accommodate heavier vehicles. When estimating the possible benefits and negative impacts of HCVs, the development of technologies and vehicles should be acknowledged as these could offer solutions for some of HCVs' challenges.

\section{Methodology}

In this research, quantitative data is used to calculate the actual impacts of new maximum weight limits of articulated trucks in Finland. Data from the Goods Transport by Road survey (GTRS) by Statistics Finland [29] on national road freight transport in 2013-2017 is used as the main data source. The survey describes the transport operations of trucks registered in Finland based on a continuous sample survey in which annually 10,000 truck owners are asked to provide data on their trucks and operations over three or four consecutive survey days. The data include both domestic and international operations, but only domestic operations are considered here, because weight limit increases could not be utilized in international operations. This data source does not include data on fuel consumption. Hence, fuel consumption data from LIPASTO [30] and NTM [31] have been added to the analysis following the methodology outlined in Liimatainen \& Pöllänen [32].
There are data from around 10,000 truck trips each year. The following key data, which is provided by the truck owners on all the operations of a lorry over three or four survey days, is used for each trip:

- trip length $(\mathrm{km})$

- number of axles in truck and trailer

- own weight $(\mathrm{kg})$

- maximum total weight $(\mathrm{kg})$, i.e. weight limit of a fully loaded truck and trailer combination as defined in vehicle registration

- payload weight $(\mathrm{kg})$

- type of payload (originally 45 commodity types, here aggregated to $20+$ forestry, according to the NST2007 commodity classification).

The following information is calculated based on the data:

- total vehicle kilometres

- total tonnes

- total tonne-kilometres

- total number of trips

- total fuel consumption and $\mathrm{CO}_{2}$ emissions.

The following process is followed in order to analyse the benefits of the HCV implementation in Finland:

- each trip is checked to see if the maximum total weight is greater than the former weight limit for a truck with certain number of axles, e.g. greater than $60 \mathrm{t}$ for 8 -axle vehicle combination.

- if yes,

- the old maximum payload weight is calculated as the difference of old weight limit and own weight, - the extra payload weight allowed by new weight limits is then calculated as the difference of payload weight and old maximum payload weight, - the extra tonne-kilometres are then calculated by multiplying the extra payload weight with the trip length,

- the extra tonne-kilometres of each trip are then expanded to correspond the national total using the sample multipliers,

- total extra tonne-kilometres are then divided by the old maximum payload weight of a truck, i.e. $40 \mathrm{t}$. This results in total vehicle kilometres saved using the new higher weight limits.

- Then, total vehicle kilometres saved is multiplied with cost factors by vehicle type (Table 1 ) to get the cost savings. There are five vehicle types (part load, forestry, long-haul, tanker and bulk, construction), and commodities are assigned to these vehicle types as presented in Table 2. Cost factors are calculated 
Table 2 Operating cost used to calculate cost savings (based on Vierth et al. [33], except fuel consumption on laden trips calculated from GTRS data using methodology by Liimatainen \& Pöllänen [32])

\begin{tabular}{|c|c|c|c|c|c|}
\hline Vehicle type & Part load & Forestry & Long-haul distribution & Tanker and bulk & Construction \\
\hline $\mathrm{SEK} / 10 \mathrm{~km}$ & 130 & 149 & 144 & 178 & 195 \\
\hline Share of personnel costs & $36 \%$ & $33 \%$ & $44 \%$ & $42 \%$ & $38 \%$ \\
\hline Share of fuel costs & $30 \%$ & $30 \%$ & $26 \%$ & $22 \%$ & $22 \%$ \\
\hline Share of other vehicle costs & $35 \%$ & $37 \%$ & $30 \%$ & $37 \%$ & $40 \%$ \\
\hline Exchange rate & \multicolumn{5}{|c|}{$1 \mathrm{SEK}=0.0984 \mathrm{EUR}$} \\
\hline Personnel costs (€/km) & $0.46 €$ & $0.48 €$ & $0.62 €$ & $0.74 €$ & $0.73 €$ \\
\hline Fuel costs $(€ / \mathrm{km})$ & $0.38 €$ & $0.44 €$ & $0.37 €$ & $0.39 €$ & $0.42 €$ \\
\hline Other vehicle costs (€/km) & $0.45 €$ & $0.54 €$ & $0.43 €$ & $0.65 €$ & $0.77 €$ \\
\hline Total (€/km) & $1.29 €$ & $1.47 €$ & $1.42 €$ & $1.77 €$ & $1.92 €$ \\
\hline Fuel consumption $(1 / 100 \mathrm{~km})$ on laden trips & 30.3 & 66.7 & 37.5 & 46.5 & 58.1 \\
\hline
\end{tabular}

for each vehicle type based on the ones presented by Vierth et al. [33] and changing the currency from SEK to EUR using the conversion rate 1 SEK = 0,0984 EUR, which is estimated based on the EUR/ SEK exchange rate during most of 2008 [34] and taking into account the changes in the freight transport cost index between 2010 and 2014 [35]. The resulting costs are presented in Table 2 . - Next, fuel savings and $\mathrm{CO}_{2}$ emission reductions are calculated based on the total vehicle kilometres saved by using average fuel consumption on laden trips (presented in Table 2) calculated for each vehicle type using the methodology outlined in Liimatainen \& Pöllänen [32]. The fuel consumption saved is calculated based on the average fuel consumption on trips in which extra capacity of HCVs was not used.

- Finally, $\mathrm{CO}_{2}$ reductions are calculated by multiplying the fuel savings by the emission factor $2.66 \mathrm{~kg} \mathrm{CO}_{2} /$ litre

The results of the analyses are presented mostly by quarter in order to analyse the uptake of the $76 \mathrm{t}$ vehicles combinations.

\section{Results}

\subsection{Implementation and utilization of higher maximum payload}

The higher weight limits, detailed above in Table 1 , were introduced in the beginning of October, i.e. from the fourth quarter of 2013. An alteration inspection had to be done to an old truck or a new truck had to be registered to be able to benefit from the higher weight limits. Hence, the implementation of higher weight limits has progressed gradually, as evident from Fig. 1.

The over $60 \mathrm{t}$ total weight vehicles have quickly gained a significant share of total haulage. However, the question arises, has the extra capacity actually been used? As can be seen from Fig. 1, the extra capacity seems to have been used to a large extent. On average 79\% (range of $72 \%$ to $88 \%$ between quarters) of haulage (tonne-kilometres, tkm) with over $60 \mathrm{t}$ vehicles have used at least some of the extra capacity provided by the new regulation, i.e. the payload has been larger than previously possible.

Furthermore, the extra capacity is typically fully utilised. The maximum extra payload weights for articulated trucks with 7,8 and 9 axles are 4,8 and $16 \mathrm{t}$, respectively. Over the period from Q4/2013 until Q4/ 2017 , the 7- and 8-axle vehicles have had average extra payloads of $3.6 \mathrm{t}$ and $6.8 \mathrm{t}$, respectively, which are close to the maximum. However, the extra capacity is not as well utilized with the 9-axle vehicles, as extra payload average has been $12.6 \mathrm{t}$. This is likely due to the fact that the volumetric capacity is the same between the vehicles and to fully utilise the maximum weight of a 9-axle vehicle requires a very dense load. It is worth pointing out that this is one reason for allowing the longer than $25.25 \mathrm{~m}$ vehicle combinations in Finland in January 2019. The extra payload made possible by the new regulation has been on average $6.9 \mathrm{t}$ (ranging from 4.4 to 9.6 between quarters).

When the uptake of over $60 \mathrm{t}$ vehicles is analysed on a commodity level, it can be seen that the commodities in which the payload is limited by weight rather than cargo volume have implemented and utilized the extra capacity the most. In $2017,46 \%$ of total haulage was made with over $60 \mathrm{t}$ vehicles, which used the extra capacity. However, only four commodities out of 20 have a larger share than the average (Table 3). These commodities are forestry (91\%), mining and quarrying (64\%), chemical products (51\%) and coke and petroleum products (61\%). There are eight commodities (household and office removals; unidentifiable goods; mail; transport equipment; textiles; furniture; empty containers and packaging; other goods and empty) in which less than $10 \%$ of total 


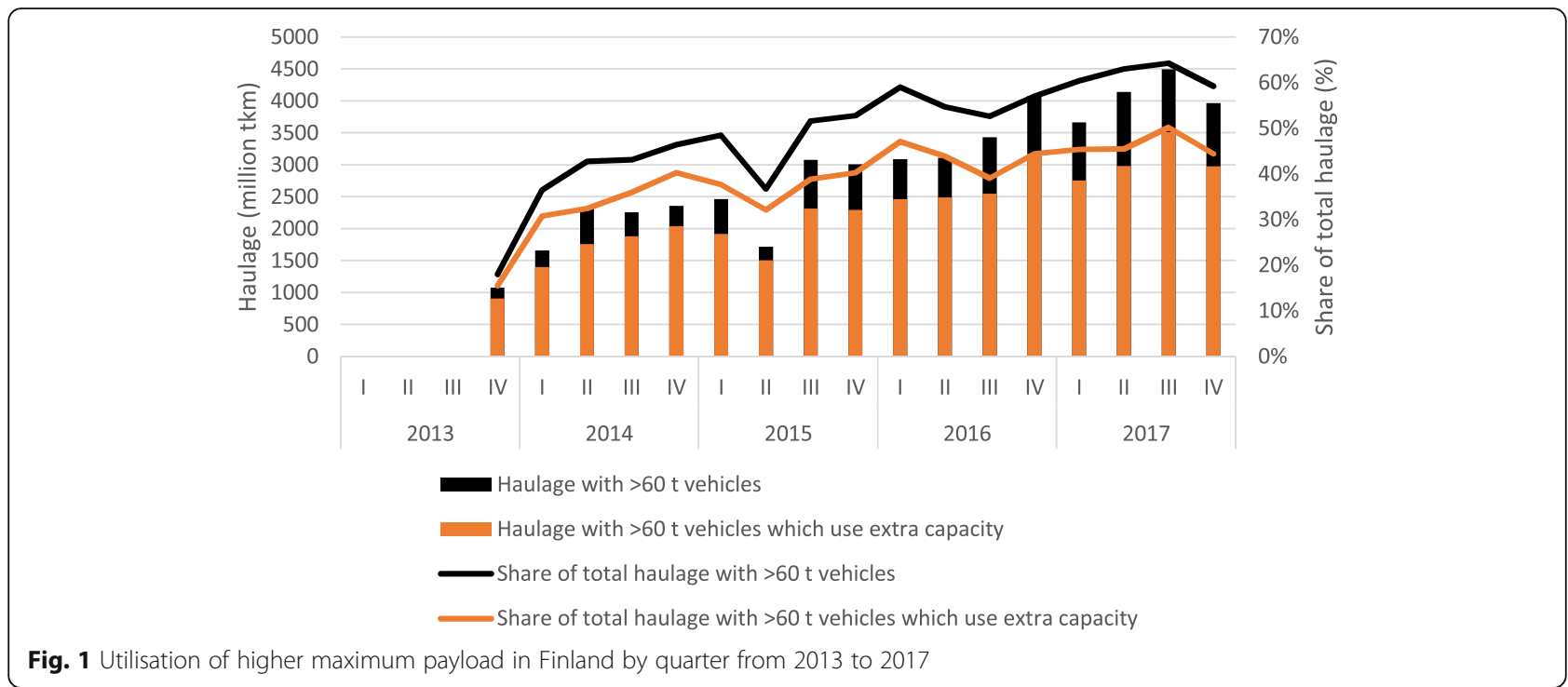

haulage benefited from the extra capacity in 2017. For some commodities (e.g. food products; metal products; household and office removals; unidentifiable goods) there is a large variation between years and quarterly analysis on commodity level is not possible due to large variation in the amount of data.

\subsection{Effect on average payload and mileage}

As it was shown, the over $60 \mathrm{t}$ articulated trucks have been taken into use and are utilized quite fully. A question then arises on effects of HCVs on the average payload of various vehicle types. Figure 2 shows an increasing trend of the average load on laden trips with

Table 3 Share of haulage (of tkm) benefiting from the extra capacity by commodity group

\begin{tabular}{|c|c|c|c|c|c|c|}
\hline Commodity group with NST number & Vehicle type & Q4/2013 & 2014 & 2015 & 2016 & 2017 \\
\hline Forestry & Forest raw material & $53 \%$ & $83 \%$ & $86 \%$ & $85 \%$ & $91 \%$ \\
\hline 03 Mining and quarrying & Construction & $13 \%$ & $45 \%$ & $42 \%$ & $60 \%$ & $64 \%$ \\
\hline 07 Coke and petroleum products & Tanker and bulk & $0 \%$ & $17 \%$ & $39 \%$ & $31 \%$ & $61 \%$ \\
\hline 08 Chemical products & Tanker and bulk & $13 \%$ & $31 \%$ & $56 \%$ & $56 \%$ & $51 \%$ \\
\hline 06 Wood products & Long-haul distribution & $13 \%$ & $36 \%$ & $32 \%$ & $43 \%$ & $43 \%$ \\
\hline 14 Waste & Construction & $3 \%$ & $24 \%$ & $22 \%$ & $33 \%$ & $39 \%$ \\
\hline 01 Agricultural products w/o forestry & Long-haul distribution & $11 \%$ & $22 \%$ & $27 \%$ & $22 \%$ & $39 \%$ \\
\hline 09 Glass, other non-metallic mineral products & Long-haul distribution & $13 \%$ & $37 \%$ & $33 \%$ & $48 \%$ & $38 \%$ \\
\hline 02 Coal & Tanker and bulk & & $100 \%$ & $30 \%$ & $39 \%$ & $24 \%$ \\
\hline 04 Food products & Long-haul distribution & $1 \%$ & $9 \%$ & $24 \%$ & $17 \%$ & $24 \%$ \\
\hline 10 Metal products & Long-haul distribution & $9 \%$ & $30 \%$ & $19 \%$ & $39 \%$ & $22 \%$ \\
\hline 18 Grouped goods & Long-haul distribution & $0 \%$ & $10 \%$ & $13 \%$ & $18 \%$ & $21 \%$ \\
\hline 11 Machinery and equipment & Part load & $32 \%$ & $1 \%$ & $2 \%$ & $2 \%$ & $19 \%$ \\
\hline 15 Mail & Part load & $0 \%$ & $0 \%$ & $0 \%$ & $4 \%$ & $8 \%$ \\
\hline 16 Empty containers, packaging & Part load & $0 \%$ & $0 \%$ & $0 \%$ & $0 \%$ & $5 \%$ \\
\hline 17 Household and office removals & Part load & $0 \%$ & $0 \%$ & $5 \%$ & $37 \%$ & $0 \%$ \\
\hline 19 Unidentifiable goods & Long-haul distribution & $0 \%$ & $0 \%$ & $0 \%$ & $26 \%$ & $0 \%$ \\
\hline 12 Transport equipment & Part load & $0 \%$ & $1 \%$ & $6 \%$ & $2 \%$ & $0 \%$ \\
\hline 05 Textiles & Part load & $0 \%$ & $0 \%$ & $0 \%$ & $0 \%$ & $0 \%$ \\
\hline 13 Furniture & Part load & $0 \%$ & $0 \%$ & $0 \%$ & $0 \%$ & $0 \%$ \\
\hline 20 Other goods and empty & & $0 \%$ & $0 \%$ & $0 \%$ & $0 \%$ & $0 \%$ \\
\hline ALL COMMODITIES & & $16 \%$ & $35 \%$ & $37 \%$ & $43 \%$ & $46 \%$ \\
\hline
\end{tabular}


every vehicle type. However, this figure should be interpreted cautiously because there is great fluctuation between quarters depending on the amount of data that various commodities have had in the sample. The increase has been particularly steep with forest raw material vehicles, with which the average load has increased from $31 \mathrm{t}$ to $41 \mathrm{t}$ based on the linear trend line. Also for tanker and bulk vehicles the trend line shows steep increase from $22 \mathrm{t}$ to $25 \mathrm{t}$. The total annual average payload increased from $13.3 \mathrm{t}$ in 2013 to $15.3 \mathrm{t}$ in 2014, 16.3 $\mathrm{t}$ in $2015,17.0 \mathrm{t}$ in 2016 and $16.5 \mathrm{t}$ in 2017 . This increase can be regarded as a positive impact from the energy efficiency perspective and it shows that the impact on average loads has been significant.

The utilization of the extra capacity has also lead to significant vehicle mileage savings in Finland compared to a situation without the weight increases. If the haulage $(\mathrm{tkm})$ now operated with over $60 \mathrm{t}$ total vehicle weight would have been operated with the old maximum weight limit of $60 \mathrm{t} \mathrm{GVW,} \mathrm{in} \mathrm{total} 225$ million additional vehicle kilometres would have been needed from October 2013 until the end of 2017 . This is $2.9 \%$ more than the actual mileage. Figure 3 shows the increase in the amount of saved mileage. There was steady increase until the third quarter of 2014 and then saved mileage seemed to saturate around 12 million $\mathrm{km}$ and $2.5 \%$ of total truck mileage per quarter during 2015. Thereafter it increased again to around $3.5 \%$ and 15 million $\mathrm{km}$ per quarter in 2016 and first half of 2017, with a peak of 5\% in Q3/2017. However, when comparing different years we must consider also general economic development, which has shown positive development from 2014 to 2017 and hence affected the total demand of freight transport (Fig. 4).
Before new regulation and the increase in the maximum vehicle weight, Nykänen and Liimatainen [5] estimated in a maximum impact analysis that 139 million $\mathrm{km}$ could be saved annually from 7- to 9-axle vehicles' mileage, if all suitable haulage with 7- and 8-axle combination would transfer to fully laden 9-axle vehicles. As can be seen from Fig. 3, there has been a significant transfer from 7-axle vehicles to 9-axle vehicles, but the savings in vehicle $\mathrm{km}$ were in total 81 million $\mathrm{km}$ in 2017 , which is $58 \%$ of the estimated maximum saving. In 2017 , the total mileage with 7 - to 9 -axle vehicles was 860 million $\mathrm{km}$ with $26 \%, 49 \%$ and $24 \%$ of that by $7-, 8$ and 9-axle vehicles, respectively. The share of 7-axle vehicles decreased from $55 \%$ in Q4/2013, while shares of 8 -axle and 9-axle vehicles increased from $43 \%$ and $2 \%$ in Q4/2013, respectively.

The 9-axle vehicles have been especially utilized in those sectors that have benefited from extra capacity as was seen in Table 3 . Around $49 \%$ of mileage of forestry were carried with 9-axle vehicles in 2017. Hence, also the savings in vehicle kilometres come mainly from this weight-restricted commodity, as can be seen in Table 4.

Table 4 shows that by far the largest benefactor of the HCVs is forestry sector in which the saved vehicle kilometres are equal to $22 \%$ of actual vehicle kilometres driven in 2017. Forestry also represents 44\% of the total vehicle kilometres saved if the saved empty running (which are included in the NST commodity ' 20 Other goods and empty') kilometres are assigned to other commodity types using the average empty running share of $21 \%$ of total haulage. However, the empty running share in forestry is likely to be greater than average [36] so forestry represents even larger share of total mileage savings.

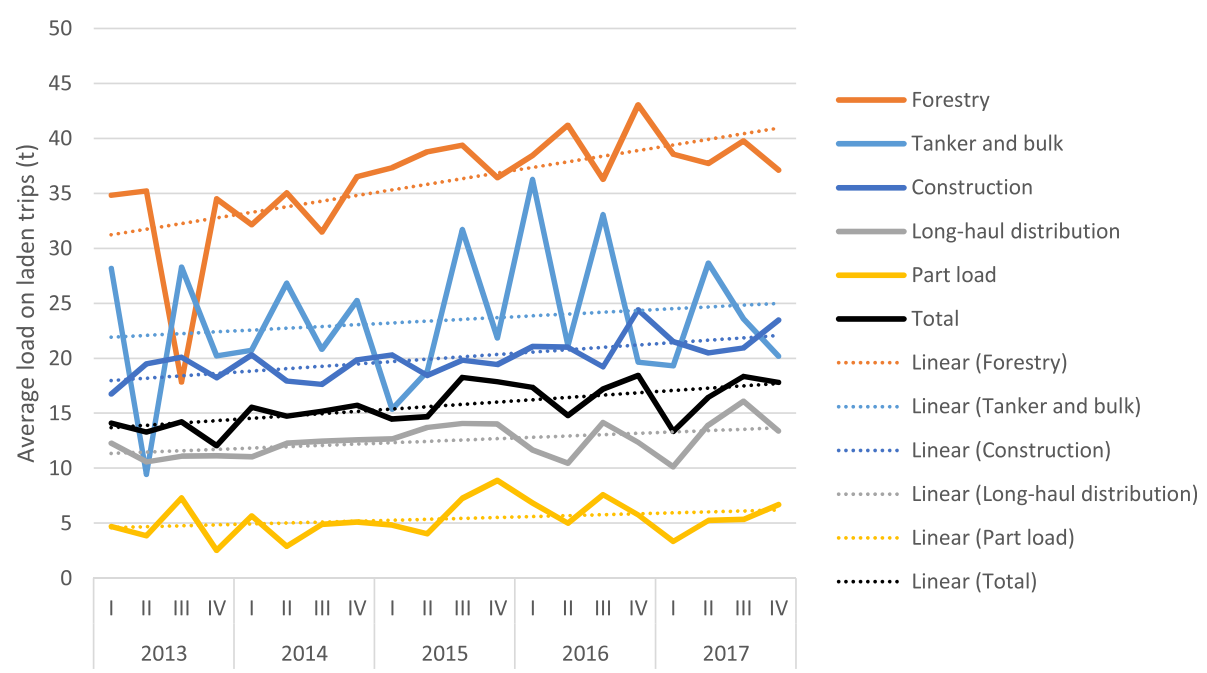

Fig. 2 Average payload weight on laden trips by vehicle type quarterly from 2013 to 2017 


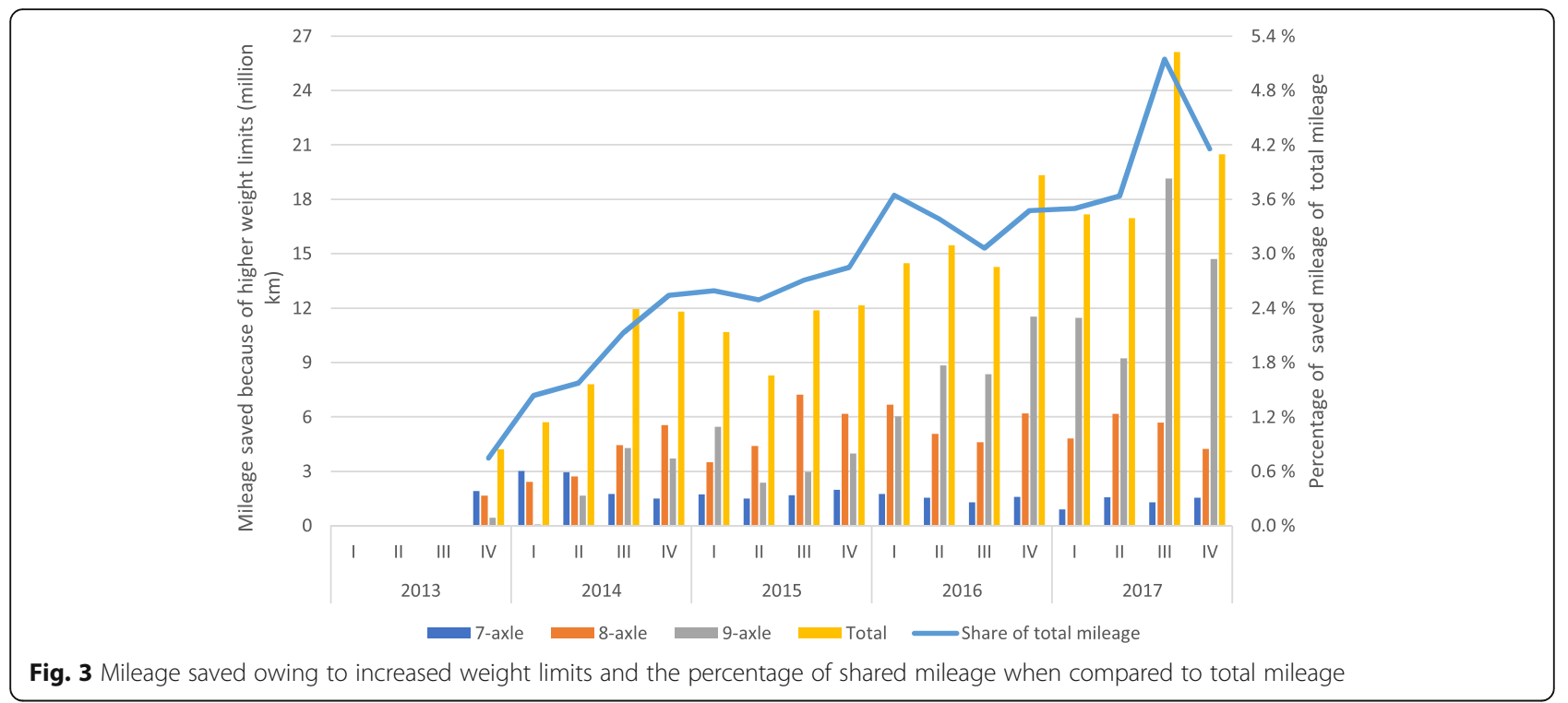

\subsection{Economic effects}

Finnish Ministry of transport and communications [37] estimated that cost savings of approximately 1.6-3.2 billion $€$ could be achieved over a 20-year period due to the higher weight limits. The study by Nykänen and Liimatainen [5] estimated that the maximum savings could be $183 \mathrm{M} €$ annually and 3.4 billion $€$ over a 20 -year period. This was the absolute maximum estimate of the benefits, which could be achieved if all haulage carried out with $90 \%$ weight utilization rate would instead be carried out by fully using the new maximum weight limits. These estimates also included savings from the utilization of extra capacity in 2- to 5-axle trucks. However, we can now see that the utilization of higher weight limits have been virtually non-existent with these trucks and these are hence not considered in this study. Based on the actual use of HCVs, the realized cost savings can now be calculated.

Table 5 shows that the cost savings have risen yearon-year from the reduced vehicle kilometres due to increased weight limits and reached 126 million $€$ in 2017. The actual savings are thus much lower than the $183 \mathrm{M} €$ maximum savings estimated in Nykänen and Liimatainen [5], in which it was assumed that all weight-restricted haulage done with 7- or 8-axle vehicles would use 9-axle vehicles instead. In Nykänen and Liimatainen [5], there was a lower figure for costs per $\mathrm{km}$, because the same costs, derived from Tervonen et al. [38], was used for all vehicle types. In this study, different costs for each of the

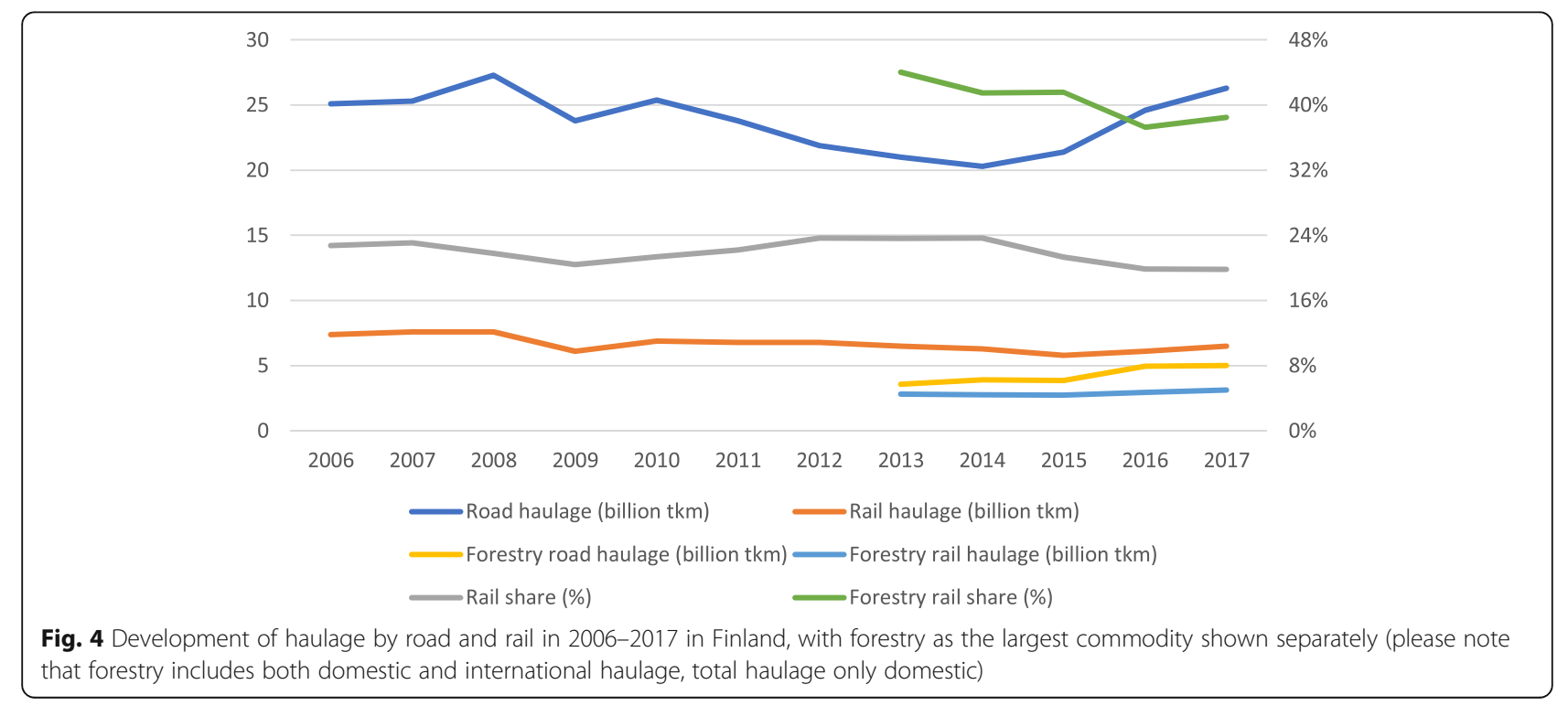


Table 4 Vehicle kilometres saved by using HCVs in 2017 by commodity

\begin{tabular}{|c|c|c|c|}
\hline $\begin{array}{l}\text { Commodity } \\
\text { group with } \\
\text { NST number }\end{array}$ & $\begin{array}{l}\text { Saved vehicle } \\
\mathrm{km} \text { (million } \mathrm{km} \text { ) }\end{array}$ & $\begin{array}{l}\text { Total vehicle } \\
\text { km (million km) }\end{array}$ & $\begin{array}{l}\text { Saved } v \mathrm{~km} \text { as } \\
\% \text { of total } \mathrm{vkm}\end{array}$ \\
\hline $\begin{array}{l}01 \text { Agricultural } \\
\text { products w/o } \\
\text { forestry }\end{array}$ & 2.8 & 70 & $3.9 \%$ \\
\hline Forestry & 26.4 & 122 & $21.6 \%$ \\
\hline 02 Coal & 0.0 & 1 & $2.8 \%$ \\
\hline $\begin{array}{l}03 \text { Mining and } \\
\text { quarrying }\end{array}$ & 8.6 & 100 & $8.6 \%$ \\
\hline 04 Food products & 3.1 & 244 & $1.3 \%$ \\
\hline 05 Textiles & 0.0 & 17 & $0.0 \%$ \\
\hline 06 Wood products & 4.5 & 135 & $3.3 \%$ \\
\hline $\begin{array}{l}07 \text { Coke and } \\
\text { petroleum } \\
\text { products }\end{array}$ & 3.4 & 55 & $6.2 \%$ \\
\hline $\begin{array}{l}08 \text { Chemical } \\
\text { products }\end{array}$ & 2.4 & 54 & $4.6 \%$ \\
\hline $\begin{array}{l}09 \text { Glass, other non- } \\
\text { metallic mineral } \\
\text { products }\end{array}$ & 2.8 & 81 & $3.5 \%$ \\
\hline 10 Metal products & 1.0 & 85 & $1.2 \%$ \\
\hline $\begin{array}{l}11 \text { Machinery } \\
\text { and equipment }\end{array}$ & 0.6 & 42 & $1.3 \%$ \\
\hline $\begin{array}{l}12 \text { Transport } \\
\text { equipment }\end{array}$ & 0.0 & 42 & $0.0 \%$ \\
\hline 13 Furniture & 0.0 & 10 & $0.0 \%$ \\
\hline 14 Waste & 1.4 & 63 & $2.3 \%$ \\
\hline 15 Mail & 0.0 & 56 & $0.1 \%$ \\
\hline $\begin{array}{l}16 \text { Empty containers, } \\
\text { packaging }\end{array}$ & 0.0 & 30 & $0.1 \%$ \\
\hline $\begin{array}{l}17 \text { Household and } \\
\text { office removals }\end{array}$ & 0.0 & 62 & $0.0 \%$ \\
\hline 18 Grouped goods & 3.2 & 275 & $1.2 \%$ \\
\hline $\begin{array}{l}19 \text { Unidentifiable } \\
\text { goods }\end{array}$ & 0.0 & 9 & $0.0 \%$ \\
\hline $\begin{array}{l}20 \text { Other goods } \\
\text { and empty }\end{array}$ & 20.3 & 407 & $5.0 \%$ \\
\hline Total & 81 & 1958 & $4.1 \%$ \\
\hline
\end{tabular}

five vehicle types was used (Table 2). This further increases the difference between maximum estimated benefits and actual benefits of the use of HCVs.

Cost savings from the use of HCVs increased 24\% from 2014 to 2015, 48\% from 2015 to 2016 and 29\% from 2016 to 2017. Part of the growth was due to increase in total haulage, but mainly the growth is due to 7 -axle vehicles being replaced by 9 -axle vehicles, as was presented in Fig. 3. The shares from different vehicle types has remained fairly stable as the share of cost savings of forestry has been $42-45 \%$ and long-haul distribution between 23 and $27 \%$. This indicates that the rate of replacing old 7- or 8-axle LHVs with new 9-axle HCVs has happened at a similar rate with all vehicle types.

The total cost savings cumulatively from October 2013 to the end of 2017 are $348 \mathrm{M} €$. Figure 3 shows that the savings from extra capacity have grown somewhat continuously, although there is some variation between quarters. In order to analyse whether there still is potential for additional savings, the share of haulage within the various vehicle age groups are analysed. Of the total haulage in which extra capacity was utilized, $66 \%$ of the haulage by vehicles registered in 2014-2017 was carried by 9 -axle vehicles, $33 \%$ by 8 -axle vehicles, and $1 \%$ by 7 axle vehicles. Hence, the share of 9-axle vehicles seem to have reached its maximum at around $66 \%$ of the haulage benefiting from the weight limit increase. The savings are likely to increase further as all old 7-axle vehicles currently used to carry extra capacity are replaced by new 9-axle vehicles. In 2017, the 9-axle vehicles' share of the overall haulage benefiting from weight limit increase (12.2 billion $\mathrm{tkm}$ ), was $47 \%$ (5.8 billion tkm). If 9-axle vehicles would have had the $66 \%$ share and 8 -axle vehicles $34 \%$ share of this haulage (i.e. the shares the new 9- and 8 -axle vehicles which have been registered after the weight limit increase have), approximately additional 2.3 billion tkm could transfer to 9-axle vehicles, of which 1.7 billion tkm from 7 -axle vehicles and 0.6 billion tkm from 8-axle vehicles. With the current average load of $35.1 \mathrm{t}$ for 7 -axle vehicles, $37.2 \mathrm{t}$ for 8 -axle vehicles and $45.6 \mathrm{t}$ for 9 -axle vehicles, the shift of 1.7 billion tkm from 7 -axle to 9-axle vehicles would save about 11 million $\mathrm{km}$ and shift of 0.6 billion tkm from 8 -axle vehicles to 9-axle vehicles would save about 3 million $\mathrm{km}$ in addition to current savings of 81 million $\mathrm{km}$. The total savings would then be approximately 95 million $\mathrm{km}$ (i.e. 14 million $\mathrm{km}$ more than actual savings in 2017), which would be about $4.9 \%$ of total truck mileage in 2017 .

The maximum savings of using HCVs depends also naturally on the development of total haulage and particularly the haulage of the weight-restricted commodities and especially forestry (Table 4). In 2017 as much as $57 \%$ of haulage of forestry used 9 -axle vehicles, so the share of HCVs might be saturating. However, the haulage of forestry is likely to increase in Finland because of investments in new pulp mills and biorefineries planned and made in 2017 and 2018 [39].

If the implementation of $\mathrm{HCVs}$ would saturate to around $5 \%$ of total mileage, the annual savings would be approximately $155 \mathrm{M} €$. Calculated with $1 \%$ inflation, the savings would then be approximately 2.6 billion $€$ over the 20-year period. This is within the range of 1.6-3.2 billion $€$, which was estimated by the Finnish Ministry of Transport and Communications [37], although significantly less than the estimated theoretical maximum benefits (3.4 billion $€$ ) if all suitable haulage with 
Table 5 Cost savings of using HCVs in 2013-2017

\begin{tabular}{|c|c|c|c|c|c|c|c|}
\hline & Part load & Forestry & Long-haul distribution & Tanker and bulk & Construction & Total & Savings as $\%$ of total \\
\hline \multicolumn{8}{|c|}{ Vehicle kilometres saved (million km) } \\
\hline 2013/Q4 & 0.8 & 1.8 & 0.9 & 0.1 & 0.4 & 4.0 & $0,7 \%$ \\
\hline 2014 & 0.1 & 15.8 & 9.5 & 2.4 & 6.3 & 34.0 & $1,9 \%$ \\
\hline 2015 & 0.2 & 19.4 & 12.6 & 5.3 & 5.2 & 42.7 & $2,7 \%$ \\
\hline 2016 & 0.5 & 30.2 & 18.8 & 5.2 & 8.8 & 63.5 & $3,4 \%$ \\
\hline 2017 & 0.8 & 36.2 & 23.3 & 7.1 & 13.4 & 80.9 & $4,1 \%$ \\
\hline Total & 2.3 & 103.4 & 65.2 & 20.2 & 34.1 & 225.1 & $2,9 \%$ \\
\hline \multicolumn{8}{|c|}{ Cost savings (million $€$ ) } \\
\hline 2013/Q4 & 1.0 & 2.6 & 1.3 & 0.2 & 0.7 & 5.9 & $0,7 \%$ \\
\hline 2014 & 0.1 & 23.2 & 13.4 & 4.3 & 12.1 & 53.1 & $2,0 \%$ \\
\hline 2015 & 0.2 & 28.4 & 17.9 & 9.4 & 10.0 & 66.0 & $2,8 \%$ \\
\hline 2016 & 0.6 & 44.2 & 26.7 & 9.3 & 16.9 & 97.9 & $3,6 \%$ \\
\hline 2017 & 1.0 & 53.1 & 33.0 & 12.6 & 25.8 & 125.5 & $4,4 \%$ \\
\hline Total & 2.9 & 151.6 & 92.3 & 35.7 & 65.5 & 348.0 & $3,1 \%$ \\
\hline
\end{tabular}

7- and 8-axle vehicles would transfer to fully laden 9-axle vehicles [5].

\subsection{Environmental effects}

Based on the saved kilometres, the fuel savings and $\mathrm{CO}_{2}$ emission reduction can also be calculated. Table 6 presents the results of these calculations. Fuel savings reached 44 million litres and $\mathrm{CO}_{2}$ emission reductions $118 \mathrm{kt}$ in 2017 . The $\mathrm{CO}_{2}$ reduction is about $3.6 \%$ of total road freight emissions (3.3 Mt, see [40]). The share of forestry haulage is larger in fuel savings and emission reductions (55\%) than in vehicle kilometre savings (42\%), because the fuel consumption per kilometre is higher due to worse aerodynamics and higher average load than in other vehicle types. Cumulatively in 2013-2017 HCVs have resulted in 123 million litre fuel savings and $0.3 \mathrm{Mt}$ $\mathrm{CO}_{2}$ reductions, which presents a valuable contribution towards achieving the emission reductions targets set in Finland for transport sector.

If the implementation of HCVs would increase by about $20 \%$ as estimated in the previous section, the fuel savings would be around 53 million litres and $\mathrm{CO}_{2}$ reductions approximately $0.14 \mathrm{Mt}$ annually. Over a 20year period, the $\mathrm{CO}_{2}$ reductions would be approximately $2.6 \mathrm{Mt}$.

\subsection{Modal shift}

One of the main arguments against increasing the capacity of trucks is the possible adverse effect on rail freight transport and shift from rail to road. Figure 4 shows the development of domestic rail and road haulage and rail share of total haulage in 2006-2017. During this time, the rail share has been between 19.9 and $23.7 \%$ of total haulage. Both the highest and the lowest share are from the period during which HCVs have been allowed, i.e. highest in 2014 and lowest in 2017. Hence, it seems that rail share has taken a downward step at the same time that HCVs have been in operation. There might be annual variation due to sample issues, but it seems that there has been a decrease in rail share, particularly in forestry haulage. This conclusion is further verified when both domestic and international haulage of forestry are analyzed.

In 2013, the domestic and international haulage of forestry by road and rail were 6.4 billion tkm and rail share was $44 \%$ while in 2017 the total haulage was 8.1 billion $\mathrm{t} \mathrm{km}$ and rail share had decreased to $38 \%$. In other words, forestry haulage increased by $11 \%$ on railroads while increasing by $40 \%$ on roads. It is reasonable to assume this modal shift has occurred due to economic benefits of increased vehicle weight, but other factors may have had an effect as well, so longer term development of modal shares will be needed to see the actual effects. A study from Sweden analysed the long-term effects of previous truck weight increases and highlighted that weight increases did not have short-term effects, but the share of each mode continued its long-term development [41].

However, based on these numbers it is possible to estimate the effect of modal shift on the environmental benefits on HCVs. If the share of rail haulage would have remained the same in 2017 as it was in 2013, 450 million $\mathrm{t} \mathrm{km}$ of road haulage of forestry would have remained on railways. Assuming that these would have been hauled using the average loading ( $40 \mathrm{t}$ on laden trips) and empty running ( $40 \%$ of total vkm) of forestry, the $\mathrm{CO}_{2}$ emissions from the shifted forestry haulage would be about $17 \mathrm{kt}$, which is $14 \%$ of the $\mathrm{CO}_{2}$ emission reduction in 2017 presented in Table 5. Hence, increasing the 
Table 6 Fuel and $\mathrm{CO}_{2}$ savings of using HCVs in 2013-2017

\begin{tabular}{|c|c|c|c|c|c|c|c|}
\hline \multicolumn{8}{|c|}{ Fuel consumption (I/100 km) } \\
\hline & Part load & Forestry & Long-haul distribution & Tanker and bulk & \multicolumn{3}{|l|}{ Construction } \\
\hline & 30.3 & 66.7 & 37.5 & 46.5 & \multicolumn{3}{|l|}{58.1} \\
\hline \multicolumn{8}{|c|}{ Vehicle kilometres saved (million km) } \\
\hline & Part load & Forestry & Long-haul distribution & Tanker and bulk & Construction & Total & Savings as $\%$ of total \\
\hline 2013 & 0.8 & 1.8 & 0.9 & 0.1 & 0.4 & 4.0 & $0,7 \%$ \\
\hline 2014 & 0.1 & 15.8 & 9.5 & 2.4 & 6.3 & 34.0 & $1,9 \%$ \\
\hline 2015 & 0.2 & 19.4 & 12.6 & 5.3 & 5.2 & 42.7 & $2,7 \%$ \\
\hline 2016 & 0.5 & 30.2 & 18.8 & 5.2 & 8.8 & 63.5 & $3,4 \%$ \\
\hline 2017 & 0.8 & 36.2 & 23.3 & 7.1 & 13.4 & 80.9 & $4,1 \%$ \\
\hline Total & 2.3 & 103.4 & 65.2 & 20.2 & 34.1 & 225.1 & $2,9 \%$ \\
\hline \multicolumn{8}{|c|}{ Fuel savings (million I) } \\
\hline & Part load & Forestry & Long-haul distribution & Tanker and bulk & Construction & Total & Savings as $\%$ of total \\
\hline 2013 & 0.2 & 1.2 & 0.4 & 0.0 & 0.2 & 2.1 & $0,8 \%$ \\
\hline 2014 & 0.0 & 10.5 & 3.5 & 1.1 & 3.7 & 18.9 & $1,9 \%$ \\
\hline 2015 & 0.0 & 12.9 & 4.7 & 2.5 & 3.0 & 23.2 & $2,3 \%$ \\
\hline 2016 & 0.1 & 20.1 & 7.1 & 2.4 & 5.1 & 34.9 & $3,0 \%$ \\
\hline 2017 & 0.2 & 24.1 & 8.8 & 3.3 & 7.8 & 44.3 & $3,6 \%$ \\
\hline Total & 0.7 & 68.9 & 24.5 & 9.4 & 19.8 & 123.3 & $2,6 \%$ \\
\hline \multicolumn{8}{|c|}{$\mathrm{CO}_{2}$ reduction $(\mathrm{kt})$} \\
\hline & Part load & Forestry & Long-haul distribution & Tanker and bulk & Construction & Total & Savings as $\%$ of total \\
\hline 2013 & 0.7 & 3.2 & 0.9 & 0.1 & 0.6 & 5.5 & $0,8 \%$ \\
\hline 2014 & 0.0 & 28.0 & 9.4 & 3.0 & 9.8 & 50.3 & $1,9 \%$ \\
\hline 2015 & 0.1 & 34.4 & 12.6 & 6.5 & 8.1 & 61.7 & $2,3 \%$ \\
\hline 2016 & 0.4 & 53.5 & 18.8 & 6.5 & 13.6 & 92.7 & $3,0 \%$ \\
\hline 2017 & 0.6 & 64.2 & 23.3 & 8.8 & 20.8 & 117.7 & $3,6 \%$ \\
\hline Total & 1.8 & 183.3 & 65.1 & 24.9 & 52.8 & 327.9 & $2,6 \%$ \\
\hline
\end{tabular}

maximum weight of trucks has decreased the $\mathrm{CO}_{2}$ emissions of freight transport, but there has been a rebound effect because of modal shift from rail to road.

\section{Discussion and conclusions}

Increasing the length and weight of trucks and widening the use of European modular system have been for quite some time a subject of policy debate and research interest in Europe. Research has highlighted the potential for mileage and fuel savings while noting the concerns about effects on safety and road infrastructure. Finland and Sweden have used the EMS for 25 years and are, encouraged by the good experiences, taking steps further to using vehicles longer than $25.25 \mathrm{~m}$ and heavier than $60 \mathrm{t}$. Finland increased in October 2013 the maximum weight of 7-, 8- and 9-axle vehicle combinations to 64, 68 and $76 \mathrm{t}$, respectively. This study analysed the results of that increase.
This study shows that the Finnish hauliers have implemented higher maximum weight mostly by replacing 7 axle vehicles with 9-axle vehicles. During 2017, the higher payloads have resulted in mileage savings of about $4 \%$ of the total truck mileage in Finland, or about 20 million $\mathrm{km}$ per quarter. In 2017, the HCVs resulted in cost savings of around 126 million $€$ and $\mathrm{CO}_{2}$ savings of at least $0.10 \mathrm{Mt}(0.12 \mathrm{Mt}$ without taking into account the effect of modal shift from rail to road which increased emissions by $0.017 \mathrm{Mt}$ as a maximum estimate), which equals around $3 \%$ of total trucking $\mathrm{CO}_{2}$ emissions in Finland. These savings are significant and within the range of possible savings estimated prior to the change. However, the savings do not come without infrastructure costs, which have been estimated to be around 850 million $€$ over a 20 -year period due to bridge alterations and increased pavement repairs [42]. This study estimates that the total benefits of increased truck weight could reach 2.6 billion $€$ over a 20 -year period, which 
would make the change clearly beneficial for the Finnish economy. The effects of HCVs on road safety are likely to be minor in Finland because of the prior use of EMS vehicles. Hence, increasing the maximum weight of trucks seems to be on track to overall positive results.

Based on this study, there are major differences between commodities in the uptake of extra capacity and these differences should be taken into account when the costs and benefits of longer and heavier vehicles are estimated in other countries. Majority of the benefits in Finland came from one commodity, i.e. forestry. In other countries where forestry does not have such an important role in freight transport the benefits of longer and heavier vehicles may be significantly lower. Hence, commodity level approach is required in analysing the potential benefits of LHVs or HCVs. The effects of HCVs on traffic safety have not been analysed in this study, and there is not enough data for statistical analysis on the safety effects of larger trucks. The HCT combinations (longer than $25.25 \mathrm{~m}$ or heavier than $76 \mathrm{t}$ ) have been subject to careful scrutiny in Finland and although the combinations have been involved in a few incidents, the fact that the HCT combinations were longer and/or heavier than usual have had no impact on the situations [1].

Another important aspect requiring further research is the role of HCVs in achieving the ambitious $\mathrm{CO}_{2}$ emission targets. There seems to be a growing interest by vehicle manufacturers to introduce battery electric semitrailer trucks, but battery electric trucks are not suitable for LHVs or HCVs, at least not with current battery technology. Hence, Finland has very little opportunities for electric trucks compared to countries, which use semi-trailers [43]. In addition to propulsion development, another more technology-based road freight transport development path to intensify road transport is automation and especially platooning development. Platooning research has been focusing on semitrailers (HGVs), but LHVs and HCVs may provide similar benefits without the need for technological developments. Platooning could also be studied with LHVs and HCVs to gain additional benefits.

In the short-term HCVs seem to provide a very cost efficient measure for reducing $\mathrm{CO}_{2}$ emissions, even when taking into account the infrastructure costs. However, the emission reduction costs through HCVs may increase in the future if electric HGVs become less expensive and the biofuels needed for $\mathrm{CO}_{2}$ emissions reductions in $\mathrm{HCVs}$ become more expensive. Furthermore, $\mathrm{HCVs}$ seem to have caused modal shift from rail to road in Finland, but the general aim in the EU is to promote the opposite modal shift from road to rail. Hence, increasing the vehicle length and weight may become politically difficult in the future, even though the $\mathrm{CO}_{2}$ emissions have decreased in total in Finland due to truck weight increase.

\section{Acknowledgements}

Not applicable.

\section{Authors' contributions}

$\mathrm{HL}$ was primarily responsible for writing the manuscript. MP and LN gave ideas, wrote short sections and commented. All authors read and approved the final manuscript.

\section{Funding}

This work was supported by the Kone Foundation (grant number b4b919).

\section{Availability of data and materials}

The data that support the findings of this study are available from [third party name] but restrictions apply to the availability of these data, which were used under license for the current study, and so are not publicly available.

\section{Competing interests}

The authors declare that they have no competing interests.

\section{Author details}

${ }^{1}$ Transport Research Centre Verne, Tampere University, P.O. Box 600, Fl-33014

Tampere, Finland. Vediafi Oy, Valimotie 13A, Fl-00380 Helsinki, Finland.

Received: 11 July 2019 Accepted: 6 February 2020

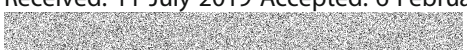

\section{References}

1. Lahti, O., Tanttu, A. (2016). "Report on wintertime High Capacity Transport (HCT) 2015-2016", Available at: https://www.trafi.fi/filebank/a/1473422710/ 7c6f1828ea16e7c6dd32fd4127c82981/22393-HCT_report_wintertime_2015-2 016.pdf

2. Finlex 4.12.1992/1257 (2020). (n.d.). Decree on vehicle's usage on roads. Available at: http://www.finlex.fi/fi/laki/ajantasa/1992/19921257 (in Finnish).

3. Lahti, O. (2018). "13 milj. Km kokemuksia HCT-rekoilla - Mitä opittiin matkan varrella", Presentation at HCT forum 14.2.2018, transport safety agency Trafi. Available at: https://www.trafi.fi/filebank/a/1519726200/bd4a0d416c0a52 a341daed4d8e1 ca824/29669-13_milj_km_kokeuksia_Otto_Lahti_Trafi.pdf. Only in Finnish

4. MINTC (2019), "Maximum length of a vehicle combination 34.5 metres", Press release 10.1.2019. Ministry of transport and communications, Finland. Available at: https://www.Ivm.fi/en/-/maximum-length-of-a-vehiclecombination-34.5-metres-995264.

5. Nykänen, L., Liimatainen, H. (2014). "Possible impacts of increasing maximum truck weight - case Finland", Transport research arena, Paris 14-17 April 2014.

6. ACEA (2016), "Reducing CO2 Emissions from Heavy-Duty Vehicles", ACEA Position Paper. Available at: https://www.acea.be/uploads/publications/ACEA_ Position Paper_Reducing_CO2_Emissions from Heavy-Duty Vehicles.pdf.

7. Breemersch, T., Akkermans, L. (2014). "GHG reduction measures for the road freight transport sector. An integrated approach to reducing $\mathrm{CO} 2$ emissions from heavy goods vehicles in Europe", ACEA final report, Brussels. Available at: http://www.tmleuven.com/project/hgvco2/ ACEAReportonHDVemissionreductionmeasuresv9.pdf.

8. Christidis, P., Leduc, G. (2009). "Longer and heavier vehicles for freight transport", JRC scientific and technical reports. Available at: http://ec.europa. eu/transport/modes/road/events/doc/2009_06_24/2009_jrc52005.pdf.

9. Glaeser, K.-P., \& Ritzinger, A. (2012). Comparison of the performance of heavy vehicles results of the OECD study: 'moving freight with better trucks'. Procedia - Social and Behavioral Sciences, 48, 106-120.

10. Leduc, G. (2009). "Longer and heavier vehicles. An overview of technical aspects", JRC scientific and technical reports. Available at: http://ec.europa. eu/transport/modes/road/events/doc/2009_06_24/2009_gigaliners_ workshop_jrc_2.pdf.

11. Rijkwaterstaat (2011), Longer and heavier vehicles in practice, Economic, logistical and social effects. The Netherlands.

12. Sanchez Rodrigues, V., Piecyk, M., Mason, R., \& Boenders, T. (2015). The longer and heavier vehicle debate: A review of empirical evidence from Germany. Transportation Research Part D: Transport and Environment, 40, 114-131. 
13. Knight, I., Newton, W, McKinnon, A., Palmer, A., Barlow, T., McCrae, I., Dodd M., Couper, G., Davies, H., Daly, A., McMahon, W., Cook, E., Ramdas, V., Taylor, N. (2008). "Longer and/or Longer and Heavier Goods Vehicles (LHVs) - a Study of the Likely Effects if Permitted in the UK: Final Report", TRL, Published Project Report PPR285. Available at: https://www.nomegatrucks. eu/deu/service/download/trl-study.pdf.

14. Lumsden, K. (2013). "Truck masses and dimensions. Impact on transport efficiency", 8th ACEA SAG workshop, Discussion Paper. Available at: https:// www.acea.be/uploads/publications/SAG_8_Trucks_Masses_Dimensions.pdf.

15. Galos, J., Sutcliffe, M., Cebon, D., Piecyk, M., \& Greening, P. (2015). Reducing the energy consumption of heavy goods vehicles through the application of lightweight trailers: Fleet case studies. Transportation Research Part D: Transport and Environment, 41, 40-49.

16. Kyster-Hansen, H. \& Sjögren, J. (2013). "Roadmap High capacity transport on Road in Sweden. Frorum for innovation in the transport sector". Available at: http://www.lindholmen.se/sites/default/files/content/PDF/2013-08-13_ roadmap hct-roads final.pdf.

17. Vierth, I., \& Haraldsson, M. (2012). Socio-Economic Effects of Longer and/or Heavier Road Transport Vehicles - The Swedish case. In HVIT12: 12th International Symposium on Heavy Vehicle Transport Technology, Sweden Available at. https://trid.trb.org/view.aspx?id=1366981.

18. Örebro Regional Development Council. (2014). "Potential of High capacity transport solutions (Road) - Two case studies in the Region of Örebro, Sweden", Available at: https://www.regionorebrolan.se/files-sv/\%C3\%96 rebro\%20l\%C3\%A4ns\%20landsting/regional\%20utveckling/rapporter\%2 0och\%20publikationer/trafik\%20och\%20samh\%C3\%A4llsplanering/grecor_ final_report_hct_case_studies.pdf.

19. Pålsson, H., Winslott Hiselius, L., Wandel, S., Khan, J., \& Adell, E. (2017). Longer and heavier road freight vehicles in Sweden: Effects on tonne- and vehicle-kilometres, CO2 and socio-economics. International Journal of Physical Distribution \& Logistics Management, 47(7), 603-622.

20. Haraldsson, M., Jonsson, L., Karlsson, R., Vierth, I., Yahya, M-R. \& Ögren, M. (2012), "Cost benefit analysis of round wood transports using 90-tonne vehicles", VTI rapport 758. Available at: http://www.vti.se/sv/publikationer/pdf/ samhallsekonomisk-analys-av-rundvirkestransporter-med-90-tonslastbilar.pdf.

21. Palander, T. (2017). The environmental emission efficiency of larger and heavier vehicles - A case study of road transportation in Finnish forest industry. Journal of Cleaner Production, 155, 57-62.

22. ETSC. (2011). "ETSC position on Longer and Heavier Goods Vehicles on the roads of the European Union", European Transport Safety Council. Available at: http://archive.etsc.eu/documents/ETSC_Position_on_Longer_and_ Heavier_Vehicles.pdf.

23. TRL. (2008). Longer and/or longer and heavier goods vehicles (LHVs) - A study of the likely effects if permitted in the UK: Final report. London: DfT.

24. Steer, J., Dionori, F., Casullo, L., Vollath, C., Frisoni, R., Carippo, F., Ranghetti, D. (2013). "A review of megatrucks - Major issues and case studies", Directorate general for internal policies. Policy department B: Structural and cohesion policies. Transport and Tourism. European Parliament.

25. Castillo-Manzano, J., Castro-Nuño, M., \& Fageda, X. (2016). Exploring the relationship between truck load capacity and traffic accidents in the European Union. Transportation Research Part E: Logistics and Transport Review, 88, 94-109.

26. Sandin, J., Bálint, A., Fagerlind, H., Kharrazi, S. (2014). "Traffic safety of heavy goods vehicles and implications for high capacity vehicles vehicles", Transport research arena 2014, Paris.

27. Kalliainen, A., Kolisoja, P., \& Haakana, V. (2015). Effect of Tire configuration on the performance of a low-volume road exposed to heavy axle loads: Mechanical modeling. Transportation Research Record: Journal of the Transportation Research Board, 2474, 174-184.

28. Kolisoja, P., Kalliainen, A., \& Haakana, V. (2015). Effect of Tire configuration on the performance of a low-volume road exposed to heavy axle loads: Response measurements. Transportation Research Record: Journal of the Transportation Research Board, 2474, 166-173.

29. Statistics Finland. (2017). "Goods transport by road", Available at: http:// tilastokeskus.fi/til/kttav/index_en.html.

30. LIPASTO. (2012). Road traffic emissions and energy consumption in Finland. Available at: http://lipasto.vtt.fi/yksikkopaastot/indexe.htm.

31. NTM. (2008). Environmental data for international cargo transport. Calculation methods and default data - mode specific issues. Road transport Europe. Network for Transport Measures, Sweden.
32. Liimatainen, H., \& Pöllänen, M. (2010). Trends of energy efficiency in Finnish road freight transport 1995-2009 and forecast to 2016. Energy Policy, 38, 7676-7686.

33. Vierth, I., Berell, H., McDaniel, J., Haraldsson, M., Hammarström, U., Yahya, M.R., Lindberg, G., Carlsson, A., Ögren, M., Björketun, U. (2008). "The effects of long and heavy trucks on the transport system", VTI rapport 605A. Available at: https://www.diva-portal.org/smash/get/diva2:675341/FULLTEXT02.pdf.

34. Freecurrencyrates.com. (2020). "Euro (EUR) and Swedish krona (SEK) Year 2008 Exchange Rate History." Available at: https://freecurrencyrates.com/en/ exchange-rate-history/EUR-SEK/2008/cbr

35. Statistics Finland. (2015). "Kuorma-autoliikenteen kustannusindeksi". Available at: http://www.stat.fi/til/kalki/2014/12/kalki_2014_12_2015-01-19_tau_002_fi. html

36. Liimatainen, H., \& Pöllänen, M. (2013). The impact of sectoral economic development on the energy efficiency and $\mathrm{CO}_{2}$ emissions of road freight transport. Transp Policy, 27, 150-157.

37. MINTC. (2013). "Better competitiveness through new masses and dimensions for heavy goods vehicles", Press release 6.6.2013. Ministry of Transport and communications, Finland. Available at: https://www.lvm.fi/ en/-/better-competitiveness-through-new-masses-and-dimensions-forheavy-goods-vehicles-792326.

38. Tervonen, J., Ristikartano, J., Sorvoja, S. (2010). Tieliikenteen ajokustannusten yksikköarvojen määrittäminen - Taustaraportti 2010. Liikenneviraston tutkimuksia ja selvityksiä 33/2010.

39. Dahl, O. (2017). "Renaissance in Finnish forest industry investments", NC Partnering Newsletter 10/2017. Available at: https://us13.campaign-archive. $\mathrm{com} / ? \mathrm{e}=[\mathrm{UNIQID}] \& \mathrm{u}=434118 \mathrm{~b} 6 \mathrm{c} 6195 \mathrm{a} 8 \mathrm{c} 2 \mathrm{a} 3 \mathrm{ea} 7 \mathrm{a} 63 \mathrm{kid}=\mathrm{eede} 586451$

40. VIT 2019. "Road traffic emissions in Finland 2017". Available at: http://lipasto. vtt.fi/en/liisa/all.htm.

41. Vierth, I., Lindgren, S., \& Lindgren, H. (2018). Vehicle weight, modal split, and emissions - An ex-post analysis for Sweden. Sustainability, 10, 1731.

42. Puurunen, J. (2013). "Valtioneuvoston asetus ajoneuvojen käytöstä tiellä annetun valtioneuvoston asetuksen muuttamisesta. Muistio 27.3.2013. Liikenne- ja viestintäministeriö.

43. Liimatainen, H., van Vliet, O., \& Aply, D. (2019). The potential of electric trucks An international commodity-level analysis. Applied Energy, 236, 804-814.

\section{Publisher's Note}

Springer Nature remains neutral with regard to jurisdictional claims in published maps and institutional affiliations.

\section{Submit your manuscript to a SpringerOpen ${ }^{\circ}$ journal and benefit from:}

- Convenient online submission

Rigorous peer review

- Open access: articles freely available online

- High visibility within the field

- Retaining the copyright to your article

Submit your next manuscript at $\boldsymbol{\nabla}$ springeropen.com 